\title{
Motifs of Passage into Worlds Imaginary and Fantastic
}

\author{
F. Gordon Greene \\ Sacramento, $C A$
}

\begin{abstract}
In this paper I match phenomena associated with the passage into otherworlds as reported during out-of-body and near-death experiences, with imagery associated with the passage into otherworlds as depicted in classic modern fantasies and fairy tales. Both sources include sensations of consciousness separating from the body, floating and flying, passage through fluidic spaces or dark tunnels toward bright lights, and emergence into supernatural worlds inhabited by souls of the deceased and by higher spiritual beings; and both describe comparable psychophysical initiatory factors. I introduce a metaphysically neutral depth psychology to explain these parallels, examine two metaphysically opposed extensions to this depth psychology, and consider several implications of a transcendental perspective.
\end{abstract}

\section{Introduction}

The prospect of a fantastic journey leading into realms of supernatural wonder has always fired the human imagination and probably always will. Such a journey may involve a voyage to remote islands or continents hidden in uncharted seas, a trek off the edge of the Earth's flat surface, a descent into the gloomy underworld below, an ascent into the starry heavens above, or a passage through a magical portal into dimensions unseen. Whatever the pathway, the possibility of such a fantastic journey speaks irresistibly to some deep facet of human nature, this is a facet possessed of a longing that must be appeased, if not fulfilled, in the realm of human imagination, if not in that of some extra mundane reality.

Mr. Greene is a free-lance writer whose principal interests have been parapsychology, religion, and metaphysics. Reprint requests should be addressed to Mr. Greene at P.O. Box 163683, Sacramento, CA 95816. 
In myth, saga, fairy tale, and fantasy, the theme of the fantastic journey has enthralled audiences. My reading of this literature has led me to a profound but previously unexplored relationship linking literary fantastic journeys to the experiential fantastic journey chronicled by out-of-the-body experiencers (OBErs) and near-death experiencers (NDErs). While several scholars have touched upon this relationship as evidenced in myths and revelatory literature (Grof and Halifax, 1977; Grof and Grof, 1980; Zaleski, 1987; Kalweit, 1988; Heinberg, 1989) and several others in modern literature (Greene, 1981; Greene and Krippner, 1990; Flynn, 1984; Straight, 1984; Moody and Perry 1988), no researcher has examined the relationship between literary and experiential fantastic journeys systematically or in depth.

That statement was true until the recent publication of Ioan Couliano's ground-breaking Out of this World (1991). Couliano's book provided the first historical overview of the relationship between literary and experiential fantastic journeys. Elsewhere (Greene, 1986) I observed that no general history of the NDE existed. With Couliano's work, this gap has been largely closed.

However, the real strength of Couliano's contribution lies not in any detailed analysis of the works he examines but rather in the impressive range of literatures his methodology encompasses. In the present paper, I introduce a complementary analysis of the relationship between literary and experiential fantastic journeys. My approach is to examine fewer works but in more detail than did Couliano. My primary emphasis is to illustrate how examples of literary fantastic journeys in classic modern fantasies and fairy tales correlate with experiential fantastic journeys. I will also attempt to make sense of why these parallels exist in the first place.

In this genre of fantastic literature, literal belief in the existence of the supernatural is often replaced by a figurative or whimsical belief. This "other realm" may not even be openly conceived of as supernatural, but rather as merely a product of the author's imagination. This shift in reality conceptions undoubtedly came about, at least in part, as a response to the rise of scientific materialism beginning in 17th century Europe. Yet these modern fantasies and fairy tales are typically structured within the contexts of cosmological beliefs about the supernatural predating the rise of modern science. Ranging in scope and sophistication from children's fairy tales to masterpieces of satire and polemic, these modern literary fantastic journeys include Jonathan Swift's satirical Gulliver's Travels (1726/1967), Lewis Carroll's twin tales of whimsy Alice in Wonderland (1865/1960) and Through the Looking Glass (1871/1960), L. Frank Baum's American 
fairy tale The Wonderful Wizard of $O z$ (1900/1982), James Barrie's visionary Peter Pan (1924/1988) and C.S. Lewis' religiously inspired The Lion, the Witch and the Wardrobe (1951). I also comment below on various film adaptations of these works and thematically related scenes from other films.

I begin by briefly reviewing the experiential components in out-ofthe-body experiences (OBEs) and near-death experiences (NDEs), which I consider members of a broader class of human experience to be termed ecstatic condition, ecstatic experience, or simply ecstasy. I shall then highlight how preliminary ecstasies sometimes blossom into full blown experiential fantastic journeys.

\section{On the Initiatory Factors and Phenomenological Structures of Ecstasy and the Experiential Fantastic Journey}

Ecstasy, as I define it, refers to the vivid sensation that one's locus of consciousness has lifted up into the air outside of one's physical body. Usually, this sense of separation occurs in conjunction with a reduced awareness or outright unconsciousness of one's physical body and of the sensory stimuli impinging upon the body. In cases where there is a real or imagined threat to life, the ecstasy is termed an NDE. Borderline sleep states, dreaming, fantasizing, meditating, contemplative praying, the ingestion of psychedelic substances, and even ordinary waking consciousness have also reportedly served as conduits to ecstasy. In these non-life-threatening circumstances, the ecstasy is called an OBE. If the ecstasy is not terminated by a more or less immediate return to physical body consciousness, experiencers may seem to partake in an ecstatic journey propelling them to any earthly location they may wish to visit. This seeming flight may even appear to launch experiencers entirely off our planet's surface to travel through celestial regions beyond. Both Carl Jung (1961) and Robert Monroe (1971) reported having been catapulted up off the face of the earth, during ecstatic conditions, to look down upon our planet as if from above. Both perceived our planet to be a radiant and living globe. Walt Whitman captured this same planetary vision in his mystical poem "Song of Myself" (1959/1855).

Yet another reported trajectory appears to lead ecstatic voyagers through fluidic spaces, dark elongated enclosures, or empty voids, to pass entirely outside the known parameters of space and time. Such voyagers may appear to pass into fantastic realms of existence and being that correspond, at least in part, to human conceptions of heaven 
and hell. Other realms, not so easily codified within the eschatological cartography of human imagination, have also been described by ecstatic voyagers (Fox, 1962; Monroe, 1971, 1985). After having moved seemingly into these other realms, and after having interacted with the inhabitants found therein, be they angels, devils, historical religious personages, souls of the deceased, or other intelligent beings defying clearcut catagorization, ecstatic voyagers return to ordinary bodily awareness.

In its highest manifestation, an ecstatic voyage culminates in a mystical experience. The ecstatic voyager seems to come into direct contact with Divine Intelligence or seems to become immersed within this intelligence. Alternately, mystically experience may involve the sense of having utterly transcended space and time to encompass, however fleetingly, all knowledge of the past, present, and future.

These apparent flights into the fantastic raise the following questions. Do experiential fantastic journeys actually launch experiencers into fantastic worlds and states of being beyond the known parameters of space and time? Or do such experiences refer only to a desperate human need to believe in the transcendent at any cost? If the former is true, such ecstatic journeys may possess more reality than most human beings may be able to endure, while remaining alive and bound to the physical universe. On the other hand, if the latter is true, this need to believe in the reality of the fantastic may be fueled by an unquenchable thirst, a thirst that may be able to draw upon the depths of the human imagination to construct any imaginable world.

Now, let me turn to a category of otherworld passage that does not present us with such questions: literary fantastic journeys that we have all grown accustomed to regarding as imaginary and unreal.

\section{Gulliver's Voyages into the Fantastic}

I will begin in the 18th century European "Age of Enlightenment" with one of the greatest satires ever written, Jonathan Swift's Gulliver's Travels. (1726/1967). In the first of these fantastic voyages, Gulliver, Swift's fictional mouthpiece, was a young seafaring gentleman of late 17th century England. He was shipwrecked aboard a British merchant ship sailing through the South Indian Ocean and waded ashore, half drowned, onto the imaginary island of Lilliput. He fell asleep in exhaustion and "woke up" the following day to find himself pinned to the beach by a series of tiny ropes under the watchful eyes of the six-inch-tall inhabitants of this realm. Following a period of 
chained captivity at the hands of these elfin people, Gulliver was unchained after swearing total allegiance to the sovereign of Lilliput. Eventually, he built a sailboat and embarked for his home shore. Picked up in the open sea by a British merchant ship, he returned to England. In later voyages, Gulliver visited Brobdingnab, an imaginary medieval island kingdom of giants; Laputa, an imaginary flying island inhabited by "spaced out" scientists; and Glubbdubdrib, an imaginary island of sorcerers. He ended his voyages with a journey to the land of the Houyhnhnms, a realm of rational horses. Through the guise of the Houyhnhnms, we learn Swift's ideas about a Utopian society ruled by the rational intellect rather than by the emotions and the various base instincts possessed by "Yahoos." For Swift, the Yahoos represented all that is contemptible and repugnant about human nature.

Swift's classic satire found amusement at the expense of the political, educational, and scientific establishments of his day and at various famous persons of his acquaintance. At a deeper level, his scathing satire focused upon the imperfections of human nature. My concern, however, is with other elements in this fantasy, related to the experience of ecstasy, however deeply hidden beneath Swift's 18th century rationalist persona and antimystical Protestant demeanor. One significant parallel between Gulliver's adventure and ecstatic experience involves the imagery of the ocean. The ocean may be viewed symbolically as a boundary separating different worlds of experiential reality from one another. The solid ground of Gulliver's home shore, England, may be seen to represent a waking level, bodily-bound form of reality. The voyage onto an open sea may be construed as a quest to separate from the conventional boundaries of human culture, to examine society and the human condition at a distance.

When Gulliver's ship was wrecked on his first voyage abroad, he almost became "submerged" in the ocean and nearly drowned. The danger of drowning has sometimes served as a catalyst for NDEs (Audette, 1982; De Quincey, 1862/1956). Submergence in water may also be seen as a form of initiation or baptism leading the initiate into a more spiritually enlightened awareness of the universe and of himor herself. After wading ashore, Gulliver collapsed from exhaustion and fell into a deep sleep. Sleep states serve as one of the most common routes into ecstatic conditions. Gulliver "awakened" the following day to find himself confronting a heretofore unexpected set of fantastic circumstances.

The South African mystic and scholar Michael Whiteman (1978) commented upon one mode of consciousness transition sometimes asso- 
ciated with ecstasy, a mode of transition highly relevant to the present theme. He observed:

In transitional states between a physical state and a psychical one, or between a psychical state and a mystical one, instead of one space gradually or suddenly displacing the other, there is sometimes a kind of dissolution of the "world" into a condition of shapeless fluidity when all we are conscious of is a substantial movement of currents eddying and interweaving in space. Then, in due course, the new "world" and our new personal form are condensed out of "the waters." (pp. 291292)

Robert Crookall (1972), a leading compiler of ecstatic experience accounts, has summarized the fluidic sensations reported by experiencers of ecstasy. He found these sensations likened by ecstatic experiencers to a "shining river," "a well of water," "a fringe, which had to be crossed-with sinister fluids," "shadow forms," and "something that is misty."

When Gulliver visited the island of sorcerers, he engaged in the "black art" of necromancy, that is summoning the dead. In that way he conversed with some of humanity's greatest historical personages, real as well as fictional. Contact with the dead is commonly found in NDErelated ecstasy. As a consequence of Gulliver's final voyage abroad, to the land of the Houyhnhnms, there emerged in Gulliver's behavior a character trait frequently found among the survivors of NDEs. Frequently, during the midst of an NDE, the experiencer does not wish to return to his or her physical body and the material universe. Relative to the conditions experienced in this apparent other world, NDErs would often prefer to give up their physical lives rather than return from the ecstatic condition. And once they have returned to physical body consciousness, some NDErs long for the ecstatic condition they have left behind. After a period of time in the Houyhnhnms's utopian realm, Gulliver did not wish to return to the human condition. When he was forced by the Houyhnhnms to leave, Gulliver decided to live as a hermit rather than return to the world of the Yahoos. Only after he was taken aboard a Portuguese merchant ship by force did he return as a captive to live among other human beings. Throughout the remainder of his life Gulliver dreamt of returning to the realm of the Houyhnhnms.

Another facet of the imagery in Gulliver's Travels relevant to this paper's theme involves the minuscule and gargantuan proportions encountered, respectively, in Lilliput and Brobdingnab. Swift may have been symbolically examining 18th-century English society and 
human nature from afar and then close up. A complementary phenomenological way of looking at these radical alterations in bodily and spatial perspectives is by analogy to ecstatic experiencers' common reports that they experience visual and bodily space distortions during their ecstasies. These distortions sometimes expand and sometimes contract or otherwise radically alter bodily sensations and spatial perspectives (Green, 1968; Crookall, 1972; Mitchell, 1981; Blackmore, 1982; Greene, 1983a). Carlos Alvarado (1982) discussed spatial imagery distortions during ecstatic conditions and noted that imagery distortions also occur during episodes of extrasensory perception (ESP). The seeming relationship between imagery distortions and ESP was documented and discussed by Rene Warcollier (1948), Jan Erhenwald (1978), and Ingo Swann (1987). Elsewhere (Greene, 1983a), I have speculated that ecstatic-experience-related spatial distortions are caused by the experiencers' emerging awareness of the curves and folds in the fabric of space and time as their consciousness ascends into a higher dimensional space.

Submergence into fluidic mediums is not the only reported mode of transition into alternate experiential realities. More commonly reported is the sensation of passing through tunnel-like enclosures. Positioned phenomenologically between the fluidic and tunnel related passageways into the extramundane may be reports of passing through whirlpools and other enclosed spaces lined by rippling, twisting, or twirling boundaries. (Gallup and Proctor, 1982).

\section{Down the Tunnel and Through the Looking Glass with Alice}

The tunnel motif was used by Lewis Carroll in Alice in Wonderland $(1865 / 1960)$. Alice, the young heroine of the story, fell down a hole in the ground in pursuit of a white rabbit attired in coat and jacket. More exactly, she floated down a tunnel that was lined with books, tea room china, and other household fineries of late 19th century England. During her descent, she underwent a paradoxical juxtaposing of consciousness states. She "fell asleep" and "dreamt" that she was playing with her kitty on the lawn above the tunnel down which she was at that very moment floating. She "awakened" in the tunnel just in time to land softly upon a pile of leaves at the bottom. The paradox is compounded when we find out at the end of her fantastic journey that she was the whole time dreaming of this fall. After completing her 
descent, she entered a bizarre, strangely configured world inhabited by a multitude of weird anthropomorphic creatures.

In addition to tunnel imagery suggestive of an experiential fantastic journey, Alice came across and interacted with fantastic humanoids and other strange creatures. She also shrank to the size of a mouse after drinking the contents of a bottle and later elongated to rather monstrous proportions after consuming a "little cake." As already noted, visual/bodily space distortions are somewhat common during ecstatic experiences. Alice ate a piece of a mushroom in another scene. Her head exploded upwards, with her neck elongating almost instantaneously until her head was positioned high above a grove of trees under which she had been standing. While so positioned, Alice found herself confronting a "mother bird." This bird, wishing to protect her nearby tree-bound nest of eggs from predators, mistook Alice for a snake in search of a meal. After a brief conversation between the two, in which the bird concluded that snakes and little girls must be the same creatures, Alice just as rapidly contracted back into her former position. Such an explosive ascent into the air, along with accompanying aerial views thereby afforded, are sometimes reported by out-ofbody experiencers. The major difference here, of course, is that only Alice's head and neck participated in this ascent while, during OBEs, the whole of the out-of-body "body" or locus of perception appears to be involved. In one sense, Alice's elongated neck, stretched very thin during this experience, took on the properties of the "silver cord" sometimes observed by ecstatic experiencers. This cord, according to occult lore, is known for its elasticity and is said to connect the astral and physical bodies.

The consumption of mushrooms is another possible initiatory parallel, in addition to her having fallen asleep to begin her fantastic journey. Mushrooms with hallucinogenic properties have reportedly served as a principal catalyst for experiential fantastic journeys (Kalweit, 1988). Hallucinogenic mushrooms have also evoked radical alterations in an experiencer's perceived bodily size and other radical changes in an experiencer's orientation to physical reality. In addition, Alice met a giant caterpillar (giant, that is, relative to Alice's diminutive dimensions at the time of the meeting) smoking opium while sitting on the mushroom, portions of which she presently consumed to cause her explosive ascent. Opium has also served as a catalyst for experiential fantastic journeys as reported by early 19th century English writers of the Romantic movement (e.g., DeQuincey, 1862/1956).

Carroll's sequel to the wonderland fantasy was entitled Through the Looking Glass (1871/1960). This second fantasy contains additional 
imagery that parallels the experiential fantastic journey. At the outset of this tale Alice, in effect, became her own reflection or double by passing through her bedroom "looking glass." This looking glass or mirror interestingly became actively fluidic when she pressed up to and then passed through it. This imagery process of passing through one's bedroom mirror to become one's own reflection or double contains imagery that parallels the OBE or initial "separation" stage of ecstasy. Scott Rogo (1978) observed that experimental OBE subjects Stuart Harary and Ingo Swann have both reported that, on occasion, their optical fields during OBEs appear to be aligned in reverse fashion to the optical fields they possess while in their physical bodies. Robert Monroe (1971), as noted by Couliano (1991) in reference to the reversal in Alice's "mirror" vision, has also reported experiencing such an optical reversal during an out-of-body state. When exploring this "mirror room," Alice did not walk but rather glided around as OBErs often report they do during their otherworldly excursions. And finally, we see again an initiatory parallel. Alice underwent this mirror passage during a dream, a common portal for OBEs, as already mentioned.

A 1936 Disney production cartoon adaptation of Through the Looking Glass (Disney and Hand, 1936) actually portrayed Mickey Mouse's translucent "spirit form" lifting up into the air out of his sleeping physical body and then passing on through the mirror. An out-of-body scene involving Mickey also occurred in Fantasia (Disney and Plumb, 1940) as Mickey, as a sorcerer's apprentice, floated up out of his body during a dream to enter the "higher spheres." There he "imagined" that he consorted with higher cosmic powers, and then awakened back on Earth into a fiasco of his own making. In the 1951 Disney version of Alice in Wonderland (Disney, Geronomi, Luske, and Jackson, 1951), which incorporated scenes from both of Carroll's Alice tales, Alice experienced a state of consciousness that was essentially an OBE. While attempting to escape from the Red Queen and her army of playing cards, Alice ran up against a door through which she apparently had to pass to exit Wonderland. She peered through the keyhole to see her "real world" self sleeping peacefully on a verdant lawn, in the shade beneath a large tree.

\section{Away to Neverland with Peter Pan}

James Barrie's Peter Pan is a tale of magical flight from a world where children must eventually grow up to the imaginary island of Neverland whose inhabitants never age. Barrie's story contains more 
than just a wealth of imagery suggestive of ecstasy. Embedded implicitly in the pages of Peter Pan, from beginning to end, is a deep appreciation of the wider ramifications of ecstatic experience. Clearly Barrie appreciated the transcendental import of the human imagination and also appreciated the relationship between dream/visionary experience and the evolution of human consciousness.

Underlying Peter Pan is the conflict Barrie saw pitting the child's state of being against that of the adult's. Barrie promoted the commonly held view with uncommon insight and surprising vigor that during the transition from childhood to adulthood the human imagination atrophies until this visionary faculty becomes exhausted or dies. Barrie drew his audience into the life affairs of a middle class English family. We witness the contrast in life values and resulting life priorities displayed by parents and children. Mr. Darling had lost all sensibility for the magical and the fantastic. He drudged through life worrying about his "stocks and shares." The imaginative faculty of his wife, Mrs. Darling, had also lost all power, although, perhaps, she retained a tenuous link to her imagination. The world of imagination was, however, still very much alive in the Darling's three children, Wendy, John, and Michael.

Near the beginning of the tale, Mrs. Darling dozed off in a chair while seeing her three children to bed. She had a dream in which the boundaries separating the "real world" from "Neverland" had grown too thin. She saw that "a strange boy [had] broken through from [Neverland]" (p. 22). Upon waking she noticed that the nursery window had blown open and that a boy had dropped onto the floor, accompanied by a strange light "no bigger than your fist." When the boy realized that she was an adult, he gnashed his teeth at her. She screamed in response and he leapt back out of the window.

Later Peter Pan returned in search of his "shadow," which he had lost in all the commotion surrounding his confrontation with Mrs. Darling. Conveniently, Mr. and Mrs. Darling had just left their house to attend a dinner engagement. Peter waited, hovering in the air outside the children's nursery room window along with his fairy companion, Tinker Bell, until the children's nightlights were extinguished. As soon as darkness covered the children's room, in through the window rushed another light, a light that was "a thousand times brighter than the night lights" (p. 37). This glow was not really a light but rather gave the impression of light by flashing about so quickly. In an instant or two this glow had been through all the drawers in the nursery and rummaged through every pocket in the wardrobe. When it settled it turned out to be Tinker Bell, a female fairy whose curvaceous 
bodily form was luminous. In leapt Peter Pan through the window behind her. While rummaging about the room himself, Peter found his shadow but could not get it to stick back onto his body. He broke down and cried. His sobs awakened Wendy. Rather than being afraid of this strange young boy crying on the floor before her, Wendy was only "pleasantly interested" (p. 38).

After some introductory conversation with Peter, Wendy agreed to sew on his shadow. In the conversation that continued along with Wendy's stitching, Peter told of his home in Neverland and how he had come to live there. In return, Wendy told Peter stories as a mother would tell to her children at bedtime. Eventually, Peter talked Wendy into coming back with him to Neverland, so that they might share her nighttime stories with his Neverland companions, the Lost Boys. She said she did not know how to fly and Peter offered to teach her. They then agreed to take along with them her two brothers, John and Michael. But first, the Darling children had to learn to fly. The prescription was simple. Peter explained that "You just think wonderful thoughts and they lift you into the air" (p.51). After the children learned to fly around the room they were prepared to embark upon their journey to Neverland. Peter Pan, Tinker Bell, Wendy, John, and Michael flew out of the Darling children's nursery room window and soared up into the night air. The direction to Neverland, said Peter, was "second [star] to the right and straight ahead to morning" (p.55). After a journey during which the children lost their sense of time, finally they arrived in Neverland. There they met the Lost Boys and engaged in a number of adventures involving pirates, Indians, mermaids, fairies, and other magical beings. Eventually, the Darling children became homesick and, after a victorious last battle against the pirates, they returned to their parents' home.

The imagery Barrie employed in this modern fairy tale clearly resembles the phenomenology of ecstasy. Even conditions conducive to the onset of ecstasy were present in this story; for example, the Darling children entered into the magical world of Peter Pan after their nighlights went out. This may be seen to indicate that the Darling children were descending into sleep. As noted, borderline sleep states sometimes initiate ecstasies. Then the light "a thousand times brighter than the night lights" entered into and illuminated their room. Experiencers of ecstasy sometimes report that the environment they enter upon seemingly shedding their physical bodies is luminous. Even one's bedroom may appear to be luminous when viewed from an out-of-body perspective. Floating through the air inside their bedroom also corresponds to a commonly reported facet in the initial stages of 
an OBE. But more provocative yet relative to the theme of the fantastic journey are Peter's directions to Neverland: "second [star] to the right and straight ahead to morning." In effect, these directions involve a passage through darkness into light. Passage through darkness into light as an entrance into the supernatural forms a central part of the literary fantastic journey at least as far back as the Epic of Gilgamesh (Sandars, 1960), originally composed close to four thousand years ago.

Barrie's tale contains numerous other examples of imagery suggestive of the ecstatic condition and of the experiential fantastic journey. He stated that "it is quite impossible to say how time does wear on in Neverland ... " (p. 101). Experiencers of ecstasy often report that their time sense is greatly altered during their fantastic journeys and that the passage of time becomes difficult if not impossible, to gauge accurately. And as already noted, the inhabitants of Neverland never grow old; that is, they are immortal. Certain of these inhabitants, it has been suggested by Michael Patrick Hearn (1988), may represent souls of the deceased. In his introductory essay on the Peter Pan fairy tale, Hearn observed that Barrie drew upon traditional Celtic fairy lore. The fairies, in Celtic tradition, sometimes spirited away unwanted children to fairy lands located in mysterious islands to the west of Britain. The fairies also escorted souls of the newly deceased away to these same mysterious islands. Barrie may be seen to have drawn upon and combined both variants of this take-away motif, as it pertains to the identity of the Lost Boys. The Lost Boys in one sense, Hearn suggested, were young children who had died after being carelessly dropped out of their baby carriages by thoughtless nannies strolling through the park. Thus, in meeting the Lost Boys, the Darling children may be seen to have come into contact with souls of the dead. As noted, seeming contact with souls of the dead is a common element in experiential fantastic journeys.

\section{Swept Up Through the Cyclone with Dorothy}

I shall now address imagery characteristic of ecstasy within L. Frank Baum's The Wonderful Wizard of $\mathrm{Oz}$ and consider additional pertinent imagery present in the 1939 film production of this classic American fairy tale (LeRoy and Fleming, 1939). Dorothy Gale, a young orphan girl living with her aunt and uncle, was the heroine in both versions of this story. 
In the book version, she traveled in her uprooted farmhouse, along with her little dog Toto, into the sky through the center of a cyclone. During this ascent, Dorothy fell asleep. Dorothy "woke up" to discover that she had been transported into a fantastic world full of lush green vegetation and vibrant rolling green hills. This fantastic land was populated by many strange creatures human to varying degrees, like the dwarfish race of Munchkins, as well as by various anthropomorphic beasts, like the Cowardly Lion, and other living beings created magically out of inanimate materials, like the Scarecrow, or through the use of some sort of fantastic mechanical technology, like the Tin Woodman. Some of these beings, like the Wicked Witch of the West and her army of flying monkeys, possessed powers that would be judged to be supernatural, were Dorothy in their presence "back in Kansas." Dorothy embarked upon a journey toward the luminous Emerald City to seek an audience with the great Wizard of $\mathrm{Oz}$ in the hope that he would help her return to Kansas.

Dorothy, as noted, fell asleep on her bed while ascending through the center of the cyclone. Sleep states, we have observed, serve as one of the most common conduits into ecstatic experiences. And passage up through this whirling vortex shares obvious parallels with the tunnel experience, a common component in experiential fantastic journeys. Other aspects of Baum's imagery suggestive of experiential fantastic journeys included the impression of having entered a world of extraordinary beauty and the interaction with assorted fantastic beings. And of the Emerald City, we may note that some experiential fantastic voyagers report having approached or even having entered into luminous cities during their ethereal peregrinations (Moody, 1977).

The movie version of this fairy tale (LeRoy and Fleming, 1939) provides us with additional material to ponder. This version was more than just a translation of the $\mathrm{Oz}$ fairy tale from a written story into film. Vital new elements infused the story complicating any effort to interpret the tale clearly. First, Dorothy was much older in the movie version. Rather than being a young child, she was on the verge of adulthood. Dorothy, in this cinema version, was knocked unconscious by a falling window frame and collapsed onto her bed. She did not physically ascend with her house through the center of the cyclone, as in the book; rather this movement took place in her "imagination." Following the cyclone, Dorothy's Aunt Em and Uncle Henry were worried that Dorothy would not regain consciousness. When Dorothy did revive, both of her guardians were immensely relieved. Did the screen writer refashioning this tale for the cinema intend to suggest that this blow to the head propeled Dorothy into an NDE? 
Within such a context, the journey to $\mathrm{Oz}$ may be looked upon as a passage to a fantastic realm that is timeless, relative to Dorothy's home in turn of the century Kansas. The variety of clothes worn in this strange land, and the range of architecture and other surrounding artifacts present there, would seem to be drawn from numerous separate historical periods upon our earth. From medieval times to early twentieth-century America, it was as if these different historical periods were present all together and interactive with one another in the land of $\mathrm{Oz}$. This commingling of various historical periods into a more expansive present moment in $\mathrm{Oz}$ may also be seen to be reflected in the fairy-like appearances and psychological dispositions of the Munchkins. They possessed in a bizarre-even grotesque--mixture, the characteristics of both children and adults. Small in bodily size and large headed, like human children, they were, at the same time, adults, within the context of the realm they inhabited. Yet they possessed many childlike interests illustrated by the existence of such organizations as the "lullaby league" and the "lollipop guild." The "Wicked Witch of the West," in this movie, was gaunt and green in color, a ghoulish appearance that is often associated with corpses. Interestingly, the land of the dead from time immemorial in European lore was located in mysterious islands to the west of Europe. And Dorothy successfully journeyed to and returned from $\mathrm{Oz}$ after capturing the broomstick of the Wicked Witch of the West. In Virgil's Aeneid (1952), the fantastic voyager Aeneas successfully entered the underworld to visit the land of the dead and returned to the realm of the living because he was in the possession of a tree branch with magical powers-the "golden bough."

Yet, this was not the only possible interpretation interwoven, as if intentionally, into the movie version of the $\mathrm{Oz}$ fairy tale. Also present for viewers to ponder was the possibility that Dorothy merely experienced a strange dream. This was the accepted interpretation of her journey by the adult characters in the movie as she revived during the final scene. In such an interpretation, Dorothy returned home, after intending to run away, full of unresolved conflicts about the fate of her beloved dog, Toto. Toto had, just a short time before, escaped the clutches of Elmyra Gulch, the mean-spirited spinster who "owned half the county." For having bitten her on the leg, Miss Gulch wished to take Toto to the sheriff to be destroyed. Dorothy, just prior to arriving home, had conversed with a roadside carnival seer. His insight into human nature went beyond the turban and crystal ball he employed in his act. This insight, derived from his rational intellect rather than from some mysterious psychic force, enabled him to see right through 
the naive and impressionable farmgirl. In attempting to persuade Dorothy that her best interests lay in returning home, he realized that a direct, common sense approach might not work. Rather than risk such a failure, he employed the feigned higher authority of the wondrous and the supernatural. He looked into his crystal ball, after deceptively fishing through her bag of belongings to find the personal effects that he would need to astound Dorothy with his clairvoyant powers. Dorothy was so struck by his psychic bamboozlement that she rushed immediately home even as a major storm was stirring.

In the "strange dream" interpretation of Dorothy's journey, Dorothy was struck on the head in the midst of a life crisis. Not only was there the conflict over Toto with Miss Gulch; at a deeper level there was the conflict of self discovery and the painful transition Dorothy was experiencing as she approached womanhood. In her dream/visionary experience, she embarked upon a rite of passage into adulthood. The content of this conflict stemmed from the immediate events in her daily life organized around her ongoing identity crisis. All of this was magnified by the powers of her imagination, given free rein amidst the backdrop of the dream/visionary environment she entered. The personalities of her farmhand friends, Zeke, Hunk, and Hickory, also became magnified in this strange visionary setting. These friends became transformed respectively into the Cowardly Lion, the Scarecrow, and the Tin Woodman. Her images of these farmhands participated with her on her journey of self discovery. The last person to interact with Dorothy before her fantastic journey, the roadside seer, became a powerful Wizard in this bizarre visionary realm. The mean-spirited Miss Gulch, whom Dorothy had already accused of being a "wicked witch," actually became a Wicked Witch in the land of $\mathrm{Oz}$. And upon Dorothy's arrival in Oz, the Witch crushed under Dorothy's house had owned the county where the Munchkins lived in the land of $\mathrm{Oz}$, much as Miss Gulch owned "half the county" in Dorothy's native Kansas.

\section{Through the Wardrobe with Lucy, Edward, Peter, and Susan}

Next I shall consider the imagery in The Lion, the Witch, and the Wardrobe (1951), the first volume in C.S. Lewis's classic Narnia series. As this story opened, four children, siblings named Peter, Susan, Edward, and Lucy, had been evacuated from London during the German air raids of World War II. They had taken up residence in the very large country estate of an elderly retired professor, far away from the 
ravages of war. The house in this estate was huge, ancient, and full of surprises, and was explored by the children. The youngest girl, Lucy, came upon a wardrobe in one of the rooms of this mysterious mansion. She opened the door of this closet-like enclosure and passed into the darkness, finding herself among old clothes and moth balls. Rummaging through this enclosure with outstretched arms, Lucy expected to momentarily bump into the back of the wardrobe. But she was amazed by the size of this storage space as she walked on and on.

Then she felt something strangely soft, cold, and powdery at her feet. Continuing on, she began to rub up against what appeared to be the branches of fir trees and then spotted a light in the distance. She looked back and could still see the open door of the wardrobe and even partially into the room she had left behind. This gave her the confidence she needed to continue on. It was nighttime and snowing wherever she was, although she knew that it was daytime and summer on the other side of the wardrobe. After a while she found herself nearing the light and saw that it emanated from a lamppost in a clearing surrounded by trees.

Lucy had entered the fantastic realm of Narnia, as she learned from conversing with a faun named Mr. Tumnus, whom she met shortly after entering Narnia. Mr. Tumnus invited Lucy to his cave to warm herself by his fire and to snack on hot tea, sardines, toast, and jelly. After a bit of hesitation, Lucy accepted and off they trudged through the snow to the abode of Mr. Tumnus. Upon arriving, while warming herself by the fireplace, Lucy spotted such volumes on Mr. Tumnus's bookshelf as Men, Monks and Gamekeepers: A Study in Popular Legend, or Is Man a Myth? Having visited for some time, Lucy informed her host that she had to return home and began her journey back. When she arrived back in her own world, Lucy rushed off to find her siblings to tell them why she had been gone for so long. When she told them she had been gone for hours they responded that she has only been absent for several minutes. When she spoke of a secret passageway leading into another world, they would not believe her. In near despair, she led them to the wardrobe but alas, it was no longer a magical doorway into another world. She now had to endure the insults of her sister and brothers.

Later, Lucy entered the wardrobe and found her way back to Narnia. Eventually, all four children passed through the wardrobe into this fantastic realm. They engaged in a series of harrowing adventures in which they met various talking animals and mythological creatures. They became engulfed in an apocalyptic struggle between good and evil. This struggle, in which Asland the lion, a Christ figure, eventu- 
ally overcame Jadis the witch, a personification of universal evil, reflected Lewis's own Christian world view.

Three elements stand out in this story as important to the present thesis. The first is the long dark passageway of the wardrobe, with a light at the end, connecting the two worlds. Once again we encounter imagery suggestive of the tunnel effect. Of particular interest here are reported cases (Green, 1968, p. 43; Gallup and Proctor, 1982, p. 27) in which ecstatic experiencers described looking back from within the tunnel or from the other end of the tunnel at the physical world they had seemingly left behind. The second is the apparent contact with supernatural beings, such as the Christ-like lion and the evil witch. And the third is the timeless quality of the children's visits to Narnia. No matter how long they had been gone, when they returned to the physical world no earthly time had passed. A sense of timelessness is often ascribed by ecstatic experiencers to their seeming journeys into the beyond (Green, 1968; Hampe, 1979)

\section{Summary and Appraisal}

The fantasy works scrutinized above all involved "make believe" voyages from the world of ordinary reality into alternate fantasy realms and back again, with the exception of Gulliver's Travels, in which the voyage was ostensibly to previously unsuspected fantastic parts of our own planet Earth. In Peter Pan, the journey was also to a remote island, though in that instance the author made clear that it was an island of the imagination. Just what the "imagination" was, for Barrie, however, remains an unsettled question. The natural laws operating in these other realms varied marginally to dramatically from the natural laws generally presumed to govern the physical universe. During their extraordinary excursions, the protagonists often found themselves in awe and wonder at their bizarre contacts with fantastic beings. After a series of otherworld adventures, the protagonists returned to the world of mundane reality.

Anyone familiar with the developmental sequence and phenomenological content of experiential fantastic journeys will recognize that the above narratives share much in common with such apparent passages into other worlds. The theme of a struggle between good and evil is sometimes present in experiential fantastic journeys, as it was in the tales of Barrie, Baum, and Lewis. While lacking in most modern experiential fantastic journeys, the theme of a struggle between good and evil was quite evident in medieval Christian NDEs (Rose, 1980; 
Zaleski, 1987). Not infrequently during experiential fantastic journeys, medieval Christian ecstatic voyagers seemed to pass successively through the outskirts of heaven and then of hell. Alternately, medieval Christian ecstatic voyagers might pass up through the aerial realm of medieval cosmology, said to be infested with demons, until they reached the Lunar sphere. Beyond this sphere lay the heavenly realms of God and Paradise (Rose, 1980; Greene, 1985-86; McDannell and Lang, 1988).

In these six fantasy works we find three modes of other-realm passage that are commonly found within the chronicles of ecstatic experiencers: (1) passage through fluidic mediums; (2) passage through darkness or tunnels toward light; and (3) a process suggestive of consciousness separating from the physical body, such as mirror passage. Images of floating, flying, and levitating in these examples of fantastic literature are also strongly suggestive of the $\mathrm{OBE}$, both visually and kinesthetically. Extrasensory perception, occasionally reported to occur during ecstasies, reveries, and dreams, also occurred in the context of these stories, such as the Wicked Witch's crystal gazing in the $\mathrm{Oz}$ fairy tale. Alterations in the time sense of the protagonists in Peter Pan and The Lion, the Witch, and the Wardrobe also correspond to alterations in the time sense of ecstatic voyagers.

Profound alterations not only in a protagonist's time sense but also in his or her sense of space were also depicted in these fantasies. Examples include the varying spatial magnitudes of worlds visited by Gulliver and the series of spatial distortions experienced by Carroll's Alice in Wonderland. As noted, profound spatial distortions are sometimes reported to occur during episodes of ecstasy. Contact with souls of the dead also formed a part of literary fantastic journeys, as exemplified in Gulliver's Travels. This same theme, I have argued, was at least implicitly present in Peter Pan and in the movie version of The Wonderful Wizard of $\mathrm{Oz}$. Contact with souls of the dead is also a common theme in the accounts of NDErs. Not infrequently, such reports are even found in the chronicles of OBErs whose journeys occurred in non-near-death related circumstances.

Initiatory parallels also abound linking literary to experiential fantastic journeys. Sleep-related states served as conduits into the fantastic in Gulliver's Travels, in both of the Alice tales, in The Wonderful Wizard of $\mathrm{Oz}$ and in Peter Pan. In Gulliver's Travels we have an additional possible trigger for ecstasy in the near-drowning Gulliver experienced during his first voyage. This may be seen to have set up a condition for a possible NDE-related entrance into ecstasy. States of extreme isolation have also been known to induce ecstatic experiences, 
such as among explorers and pioneers isolated from human contact. Both Richard E. Byrd (Rogo, 1978) and Charles Lindbergh (1953) reported entering ecstatic conditions while suffering from fatigue and removed from human contact. In this regard we may note that in later voyages, Gulliver became marooned on desert islands.

Of particular significance, in my view, is the fact that in the works of Carroll, Barrie, Baum, and Lewis, the fantastic voyagers were children. Common in children is the capacity to become easily absorbed in their imaginations. This capacity of self absorption becomes increasingly rare as human beings mature, at least in our rational Western culture. Adults capable of such absorption are far more likely to experience ecstasy than those who are not (Irwin, 1985). Thus in some sense each of these writers may have realized that there is a profound relationship between the possession of a potent imagination and access to ecstasy. Also of initiatory relevance were various organic substances present in certain of these fantasy works, known to induce ecstacy. In the Alice fantasies we have a "magic mushroom" and an opiumsmoking caterpillar. In the $\mathrm{Oz}$ fairy tale, Dorothy and her companions fell asleep after breathing the fragrance of poppies.

The parallel structures examined up until this point, however, do not exhaust the commonalities between literary and experiential fantastic journeys. I shall return to examine this question of additional common elements below.

\section{Depth Psychology: A Preliminary Discussion}

Before delving into the more esoteric reasons for these parallels, one rather obvious and seemingly natural explanation should be examined: the notion of literary convention. In this view, the authors deliberately drew upon the phenomenology of ecstatic experiences in constructing their imaginary voyages. The cogency of this simple explanation, however, is greatly reduced when we consider how sparse knowledge of ecstasy was until the late 1950s. Even in such early parapsychological classics as F.W.H. Myers's The Human Personality and its Survival of Bodily Death (1903) little attention is devoted to analyzing ecstatic experiences. Only since the late 1950 s has there been any systematic attempt to decipher the phenomenology of ecstatic experiences, beginning with the pioneering studies of Hornell Hart (1954) and Robert Crookall (1960a, 1960b). Before that time, only in the literature of occultism and mysticism could one find more than scattered references to ecstasy. All six fantasies critiqued in this paper 
were published prior to 1951 , well before knowledge of ecstasy was widespread. Thus we need to look beyond literary convention for explanation of the parallels noted above.

The human mind is multifaceted in ways that may not be immediately obvious to our ordinary state of consciousness. In addition to the physical world view to which our ordinary consciousness is accustomed, there are, I now propose, numerous other consciousness state perspectives capable of being experienced by ordinary consciousness. Access to these other perspectives, I shall assume, lies beyond the customary reach of our ordinary consciousness. One possible view of these other consciousness state perspectives, to be examined shortly, is that by learning to "move" into them, ordinary consciousness undergoes a process of psychospiritual transformation. In such a process, ordinary consciousness might be transmuting into a condition that could be called extraordinary consciousness. This is, however, only one possible understanding of what takes place during these journeys into the fantastic.

\section{Ecstasy as the Ilumination of the Human Unconscious}

During ecstasy, I now propose, our ordinary consciousness somehow moves into, or expands to include (and thereby comes to illuminate) levels of the mind of which it ordinarily is unconscious. Ordinary consciousness accomplishes this by somehow extracting its awareness, predominantly if not completely, from its usual sense-mediated focus upon the physical universe. This extraction often involves a reversal of sorts as the experiencer becomes unconscious of the physical body, or at least conscious in a setting distinct from the physical body. To the extent that the authors of classic fantasies consciously experienced ecstasy, I propose, they may have consciously incorporated something of this experience into their literary creations. However, we need not suppose that every author of a classic fantasy work has had conscious experience of ecstasy.

Jonathan Swift, I suspect, may not ever have consciously experienced ecstasy. His attitude toward the mysterious and the unexplained was that of a highly skeptical early 18th-century European rationalist. His Protestant heritage made him especially suspicious of mysticism, which was associated in England at the time with the much-hated Roman Catholic tradition. Some of these authors, then, may have constructed their fantasies by drawing unconsciously upon the con- 
tents of the normally hidden mental levels experienced consciously during ecstasy.

The human mind possesses a capacity for the unconscious association of ideas during which information filters through from the unconscious into the conscious mind. Having implanted information into the unconscious, during experiments in subliminal perception, hypnosis, and while working with split brain subjects, researchers have successfully retrieved this information by a variety of means (Budzynski, 1986; Kihlstrom, 1984; Hooper and Tersi, 1986). Sometimes the actual information lodged in a subject's unconscious mind is not retrieved, but rather related ideas emerge.

If we make the following assumptions, we can gain some appreciation of how authors with no conscious recollection of ecstasy might still "create" fantastic journeys possessing the parallel structures in question. The capacity to access information present in the unconscious applies not only to that which was implanted there during experimental situations, but also to that which was encoded in the unconscious naturally via sensory input or was inherently present in the unconscious. The point I wish to emphasize is that the selection of imagery with which to construct literary fantastic journeys is not an arbitrary act. These images are based, I propose, upon certain universal or collective mental structures in the human unconscious. Either through conscious recollection of ecstasy or through an unconscious association of ideas, the authors of classic fantasies drew upon the contents of these normally hidden mental levels.

And this, I propose, is why the parallel structures in question do exist. In ecstasy, experiencers consciously apprehend the contours of the mind beyond the customary reach of ordinary consciousness. For the composition of fantastic literature, the authors drew, either consciously through direct experience of ecstasy, or unconsciously through an association of ideas, upon the contents of these same hidden mental levels. When classic fantasies have been reembellished, as in the $\mathbf{1 9 3 6}$ Disney cartoon adaptation of Through the Looking Glass (Disney and Hand, 1936) and the 1939 film of Baum's fairy tale (Leroy and Fleming, 1939), the reembellishers, I propose, drew upon the same universal or collective mental structures in the unconscious. They were, I suggest, pulling out additional properties of these structures, properties that did not survive the original passage of this unconscious mental content into waking consciousness.

The subject matter under question, I believe, naturally bifurcates into two diametrically opposed metaphysical extensions to this depth psychology. One is an epiphenomenal approach, the other a transcen- 
dental approach. In concluding this paper, I will briefly outline these divergent metaphysics and consider several reasons why I personally favor the transcendental approach.

\section{An Epiphenomenal View of Human Nature}

While conceding all I have said about the multilevel human psyche, ordinary consciousness, and the human unconscious, the epiphenomenal approach assumes that all mental activity ultimately derives from physical sensory input. All mental activity, be it of the ordinary sense mediated variety or of the ecstatic experience variety, is a reflection, and nothing more, of events in the physical universe transmitted to the mind via the physical senses. Ordinary consciousness focused upon the physical universe, in this view, is that level of mind that most accurately interprets events in the surrounding physical universe. During dreams and other visionary experiences, such as OBEs and NDEs, experiencers are cut off from ordinary perceptual links with the physical universe.

These revelers in the imagination unknowingly engage in elaborately embellished misreadings of sensory stimuli. These stimuli while the experiencers are alive, continuously impact upon their nervous systems, however they may be misconstrued and no matter how biologically close to death such experiencers may be. One of the most sophisticated works supportive of this view of human nature is Gilbert Ryle's The Concept of Mind (1949). More recently psychopharmacologist Ronald Siegel (1980) postulated an ephiphenomenal explanation for ecstatic experiences, based upon the assumption that such experiences are caused by dissociative hallucinatory activity in the brain having nothing to do with any afterlife realm. Juan C. SaavedraAguilar and Juan S. Gómez-Jeria (1989) proposed a neurobiological model for near-death experiences that developed the epiphenomenal approach in the context of contemporary medical knowledge.

The primary weakness of the epiphenomenal approach, in my view, is that it fails to account adequately for instances of scientific discovery during dream states (Myers, 1903; Ullman, Krippner, and Vaughn, 1973); for experiences of high poetic achievement as the direct consequence of visions, such as Samuel Taylor Coleridge's "Kubla Khan" (Siegel, 1989); or for telepathic dreams (Ullman, Krippner, and Vaughn, 1973) and other space/time anomalies experienced during altered states of consciousness (Broughton, 1991). 


\section{A Transcendental View of Human Nature}

The transcendental approach, in one sense, turns the epiphenomenal view on its head. Our sensory experiences of the material universe, in this alternate view, are conceived of as shadowy reflections of a higher transcendental reality. Plato's (1924) allegory of the cave in his Republic offered us the first statement of this view in Western philosophy. During ecstatic experiences, in this view, human beings undergo a psychospiritual awakening to their higher selves. Their consciousness focus moves up from the shadowy realm of material reality into the infinitely more substantial realm of the supernatural. I have outlined specifics of such a higher dimensional model of human nature in a number of papers (Greene, 1981, 1983a, 1983b, 1984; Greene and Krippner, 1990). This higher-dimensional approach is grounded in the higher space metaphysics of such thinkers as Charles Hinton (1903), P.D. Ouspensky (1923), John Dunne (1927), Steven McLaughlin (1977, 1979, 1986), Steven Rosen, (1977) and Rudolf Rucker (1977, 1984). Couliano (1991) also proposed that a higher dimensional model of human nature may offer the most comprehensive explanation for otherworld journeys experienced during visionary states of consciousness.

Even the tunnel experience may be looked upon within the context of a transcendental theory of human nature. The "illusion" of passing through a tunnel, in this view, is caused by the participation of consciousness in an acceleration to light velocity. Having attained light speed, the experiencer encompasses a four dimensional or timeless view of the cosmos. Carl Sagan (1980) offered a tantalizing hint of how the four dimensional theory of consciousness may relate not only to the tunnel experience but also to Albert Einstein's relativity theory. In discussing the changes in perception that accompany acceleration to light velocity he observed:

As your speed increases, you begin to see around the corners of passing objects. While you are rigidly facing forward, things that are behind you appear within your forward field of vision. Close to the speed of light, from your point of view, the world looks very oddultimately everything is squeezed into a tiny circular window, which stays just ahead of you. (p. 169)

Acceleration toward light velocity, with the view of the universe bunching up before one's front in the shape of a circle, may create the illusion that one is passing through a dark tunnel toward a bright 
light. Tunnels are frequently dark and possess circular openings. Could there be a more natural way to interpret an ascent into the "fantastically real"? Steve Straight (1983) developed a tunnel theory based upon these same principles.

\section{Conclusion: Ascent into the Fantastic}

Natural ecstatics, be they mystics, poets, OBErs and NDErs, or other inspired individuals, including at least some writers of classic fantasies, may be supernaturally precocious, within the context of this higher space model. In other words, the higher dimensional sensory faculties of these persons have prematurely awakened, to varying degrees. For them, the supernatural has become natural. This leads me to the additional parallels to which I have made reference. As the ecstatic voyage merges into mystical experience, a sense of timelessness and a feeling of a higher order of reality is reported by some ecstatic voyagers. Experiencers of ecstasy often believe that they have gleaned transcendental insights into the underlying nature of the cosmos.

Classic fantasies may also be said to be "timeless." Such stories do not fall into anonymity after a period of fashionability. Rather these fantasies endure through successive generations. This ageless quality, I believe, is present in fantastic literature because this literary genre embodies timeless, archetypal truths that are always relevant to human nature. In other words, not only are the phenomenological structures of ecstasy reflected in the imagery structures of fantastic literature; the transcendental insights of high mystical experience are also implicitly embedded in these writings. This is why, I propose, we unknowingly revere these works as "classic."

Classic works of fantasy, I believe, serve not only as vehicles for readers to travel in imagination temporarily outside the harsh confines of physical reality (Rabkin, 1979). This literary genre serves in addition a higher function. Classic works of fantasy, I believe, seed our psyches for that future time when we truly shall engage in a "flight of the soul"-if not before, then on the demise of our physical bodies. This expansion of consciousness will, I believe, lift us up through the theater of the human imagination to emerge on the other side into a higher supernatural reality. The "hypersubstantial" nature of this higher world may transcend our conceptions of the dichotomy between "real. ity" and "imagination." This is why the supernatural shall, I suggest, always remain a controversial subject among "rational" human beings. 


\section{Acknowledgments}

An earlier version of this paper was presented at the First International Conference on Paranormal Research in 1988, and published in the proceedings of that conference. The author wishes to thank Stanley Krippner, Ph.D., for his helpful comments on a previous draft of this paper.

\section{References}

Alvarado, C.S. (1982). ESP during out-of-body experiences: A review of experimental studies. Journal of Parapsychology, 46, 209-230.

Audette, J.R. (1982). Historical perspectives on near-death episodes and experiences. In C.R. Lundahl (Ed.), A collection of near-death research readings (pp. 21-43). Chicago, IL: Nelson-Hall.

Barrie, J.M. (1988). Peter Pan. Montreal, Quebec: Tundra Books. (Original work published 1924)

Baum, L.F. (1982). The Wonderful Wizard of Oz. New York, NY: New American Library. (Original work published 1900 )

Blackmore, S.J. (1982). Beyond the body: An investigation of out-of-the-body experiences. London, England: Heinemann.

Broughton, R. (1991). Parapsychology: The controversial science. New York, NY: Ballantine.

Budzynski, T.H. (1986). Clinical applications of non-drug-induced states. In B.B. Wolman and M. Ullman (Eds.), Handbook of states of consciousness (pp. 428-460). New York, NY: Van Nostrand Reinhold.

Carroll, L. (1960). The annotated Alice. (M. Gardner, Ed.). New York, NY: World Publishing. (Original work published 1865 as Alice in wonderland and 1871 as Through the looking glass)

Couliano, I.P. (1991). Out of this world: Otherworld journeys from Gilgamesh to Albert Einstein. Boston, MA: Shambhala.

Crookall, R. (1960a). The supreme adventure: Analyses of psychic communication. London, England: James Clark.

Crookall, R. (1960b). The study and practice of astral projection. Secaucus, NJ: Citadel Press.

Crookall, R. (1972). The case book of astral projection. Secaucus, NJ: Citadel Press.

DeQuincy, T. (1956). Confessions of an English opium eater with its sequelae, suspiria de profundis and the English mail coach (M. Elwin, Ed.). London, England: MacDonald. (Original work published 1862)

Disney, W. (Producer), Geronomi, C., Luske, H., and Jackson, W. (Directors). (1951). Alice in Wonderland (Film). Hollywood, CA: Walt Disney.

Disney, W. (Producer), and Hand, D. (Director). (1936). Thru the mirror (Film). Hollywood, CA: Walt Disney.

Disney, W. (Producer), and Plumb, E.H. (Musical director). (1940). Fantasia (Film). Hollywood, CA: Walt Disney.

Dunne, J.W. (1927). An experiment with time London, England: Faber.

Ehrenwald, J. (1978). The ESP experience. New York, NY: Basic Books.

Flynn, C.P. (1984). Death and the primacy of love in works of Dickens, Hugo, and Wilder. Anabiosis: The Journal of Near-Death Studies, 4, 125-141.

Fox, O. (1962). Astral projection. New York, NY: University Books. 
Gallup, G., Jr., and Proctor, W. (1982). Adventures in immortality: Beyond the threshold of death. New York, NY: McGraw-Hill.

Green, C. (1968). Out-of-the-body experiences. London, England: Institute of Psychophysical Research.

Greene, F.G. (1981). A glimpse behind the life review. Journal of Religion and Psychical Research, 4, 113-130.

Greene, F.G. (1983a). The out-of-body experience, extrasomatic or intrasomatic phenomenon? A non-Euclidean higher space approach. Journal of Religion and Psychical Research, 6, 159-180.

Greene, F.G. (1983b). Multiple mind/body perspectives and the out-of-body experience. Anabiosis: The Journal of Near-Death Studies, 3, 39-62.

Greene, F.G. (1984). Accelerated cerebration: An integrated view of mysticism, creativity, and ESP. Academy of Religion and Psychical Research 1984 Annual Conference Proceedings, 61-72.

Greene, F.G. (1985-86). Father Seraphim Rose on the soul after death: A critical essay review. Vital Signs, 5(3), 8-10.

Greene, F.G. (1986). [Book review of The near-death experience: Problems, prospects, perspectives]. Journal of the American Society for Psychical Research, 80, 444-450.

Greene, F.G., and Krippner, S. (1990). Panoramic visions: Hallucination or bridge into the beyond? In G. Doore (Ed.), What survives? (pp. 61-75). Los Angeles, CA: J.P. Tarcher.

Grof, S., and Grof, C. (1980). Beyond death. The gates of consciousness. New York, NY: Thames and Hudson.

Grof, S., and Halifax, J. (1977). The human encounter with death. New York, NY: Dutton.

Hampe, J. (1979). To die is gain. Atlanta, GA: John Knox.

Hart, $H$. (1954). ESP projection: Spontaneous cases and the experimental method. Journal of the American Society for Psychical Research, 48, 121-146.

Hearn, M. (1988). Introduction to J.M. Barrie's "Peter and Wendy." In J.M. Barrie, Peter Pan (pp. 1-25). Montreal, Quebec: Tundra Books.

Heinberg, R. (1989). Memories and visions of paradise Los Angeles, CA: J.P. Tarcher.

Hinton, C.H. (1903). The fourth dimension. London, England: S. Sonnenschein.

Hooper, J., and Tersi, D. (1986). The three-pound universe. New York, NY: Dell.

Irwin, H.J. (1985). Flight of mind: A psychological study of the out-of-body experience Metuchen, NJ: Scarecrow Press.

Jung, C.G. (1961). Memories, dreams, reflections. (A. Jaffe, Ed.). New York, NY: Pantheon.

Kalweit, H. (1988). Dreamtime and inner space: The world of the shaman. Boston, MA: Shambhala.

Kihlstrom, J.F. (1984). Conscious, subconscious, unconscious: A cognitive perspective. In K.S. Bowers and D. Meichenbaum (Eds.), The unconscious reconsidered (pp. 149-211). New York, NY: John Wiley.

LeRoy, M. (Producer), and Fleming, V. (Director). (1939). The Wizard of Oz (Film). Hollywood, CA: Metro-Goldwyn-Mayer.

Lewis, C.S. (1951). The lion, the witch, and the wardrobe New York, NY: Macmillan.

Lindbergh, C. (1953). The Spirit of St Louis. New York, NY: Scribner's.

McDannell, C., and Lang, B. (1988). Heaven: A history. New Haven, CT: Yale University Press.

McLaughlin, S. (1977). On feeling good. Brookline, MA: Autumn Press.

McLaughlin, S. (1979). The relationship between physical dimensions and states of consciousness. Journal of Altered States of Consciousness, 5, 65-82.

McLaughlin, S. (1986). Dimensionality and states of consciousness. In B.B. Wolman and M. Ullman (Eds.), Handbook of states of consciousness (pp. 68-96). New York, NY: Van Nostrand Reinhold.

Mitchell, J.L. (1981). Out of body experiences: A handbook. Jefferson, NC: McFarland. 
Monroe, R. (1971). Journeys out of the body. Garden City, NY: Doubleday.

Monroe, R. (1985). Far journeys. Garden City, NY: Doubleday.

Moody, R.A., Jr. (1977). Reflections on life after life. New York, NY: Bantam.

Moody, R.A., Jr., and Perry, P. (1988). The light beyond. New York, NY: Bantam.

Myers, F.W.H. (1903). Human personality and its survival of bodily death. London, England: Longmans, Green.

Ouspensky, P.D. (1923). Tertium organum: A key to the enigmas of the world. London, England: Kegan Paul Trench Tubner.

Plato. (1924). The works of Plato. (B. Jowett, Trans.). New York, NY: Dial Press.

Rabkin, E.S. (1979). The sources of the fantastic. In E.S. Rabkin (Ed.), Fantastic worlds: Myths, tales, and stories (pp. 27-36). New York, NY: Oxford University Press.

Rogo, D.S. (1978). Mind beyond the body. New York, NY: Penguin.

Rose, H.S. (1980). The soul after death: Contemporary "after-death" experiences in the light of orthodox teaching on the afterlife Platina, CA: Saint Herman of Alaska Brotherhood.

Rosen, S. (1977). Toward a representation of the irrepresentable. In J. White and S. Krippner (Eds.), Future science (pp. 132-155). Garden City, NY: Doubleday.

Rucker, R.V. (1977). Geometry, relativity, and the fourth dimension. New York, NY: Dover.

Rucker, R.V. (1984). The fourth dimension: A guided tour of higher universes. Boston, MA: Houghton Mifflin.

Ryle, G. (1949). The concept of mind New York, NY: Barnes and Noble.

Saavedra-Aguilar, J.C., and Gómez-Jeria, J.S. (1989). A neurobiological model for neardeath experiences. Journal of Near-Death Studies, 7, 205-222.

Sagan, C. (1980). Cosmos. New York, NY: Ballantine.

Sandars, N.K. (Trans.). (1960). The epic of Gilgamesh. New York, NY: Penguin.

Siegel, R. (1980). The psychology of life after death. American Psychologist, 35, 911-931.

Siegel, R. (1989). Intoxication: Life in pursuit of artificial paradise. New York, NY: Dutton.

Straight, S. (1983). Einstein and the NDE: Straight's unprovable tunnel theory. Vital Signs, 2(4), 1, 4-5, \& 15.

Straight, S. (1984). A wave among waves: Katherine Anne Porter's near-death experience. Anabiosis: The Journal of Near-Death Studies, 4, 107-123.

Swann, I. (1987). Natural ESP. New York, NY: Bantam.

Swift, J. (1967). Gulliver's travels. New York, NY: Penguin. (Original work published 1726)

Ullman, M., Krippner, S., and Vaughan, A. (1973). Dream telepathy: Experiments in nocturnal ESP. New York, NY: Macmillan.

Virgil, (1952). Aeneid. (C.D. Lewis, Trans.). London, England: Oxford University Press.

Warcollier, R. (1948). Mind to mind. New York, NY: Creative Age Press.

Whitman, W. (1959). Song of myself. In W. Whitman, Leaves of Grass (pp. 25-86). New York, NY: Viking. (Original work published 1855)

Whiteman, J.H.M. (1978). The process of separation and return in experiences fully "outof-body." In D.S. Rogo (Ed.), Mind beyond the body (pp. 270-306). New York, NY: Penguin.

Zaleski, C.G. (1987). Otherworld journeys: Accounts of near-death experience in medieval and modern times. New York, NY: Oxford University Press. 